Martin Hellström

\title{
Världen i burken och staden av kartonger
}

\section{En studie av förpackningen i barnboken}

\author{
Förpackningens egenskaper i barnlitteraturen beskrivs här med exempel från bl.a. Astrid \\ Lindgren, Tove Jansson, Maurice Sendak, James Warhola och Inger och Lasse Sandberg. En \\ burk eller kartong ger uppslag till barnens lekar och frigörelseprocesser från de vuxna och den \\ faktiska världen. Förpackningen kan vara fantastisk så som folksagans magiska föremål, men \\ den kan också bära på kritik av hur vår miljö behandlas och hur vi lever tillsammans.
}

I den här uppsatsen vill jag visa några av förpackningens egenskaper inom barnlitteraturen. I många fall ingår de bara i den bortrinnande bakgrunden, men i flera texter och illustrationer bär de på större betydelser, som samhälls- och civilisationskritiker, både i fantastisk och mer realistisk form, eller som upplösare av beroendet till föräldrarna och som ett steg på vägen till ett eget vuxenblivande. Förpackningen kan också vara en frigörare av barnens fantasi från den faktiska världen, likt folksagans magiska föremål.

Varan omvandlas " $i$ ett konsumtionssamhälle till en bild, representation eller 'spektakel'", skriver Helena Mattsson i Arkitektur och Konsumtion. Reyner Banham och utbytbarhetens estetik. ${ }^{1}$ Walter Benjamin hävdar att konstverket, det unika objektet, som i relation till föreliggande uppsats kan översättas med folksagans unika hantverksföremål, förlorar sin laddning i den mekaniserade reproduktionsteknikens tidevarv och arkitekturteoretikern Reyner Banham ser att det moderna konsumtionsobjektet utvecklas till ett i allra högsta grad laddat föremål, enligt Mattsson. Originaliteten förflyttas till konsumtionsobjektet genom dess sekundära funktioner, dess utseende och dess förpackning. Anden flyttar från den gamla lampan till modernitetens konservburk. Förvandlingen av varan, eller dess förpackning, till bild, representation eller spektakel, finner man tydliga exempel på i barnlitteraturen. Det är sådana verk som jag här har valt att beskriva, där förpackningen bär på något mer än sin vara eller det tomrum som uppstår efter förbrukningen. Jag har valt barnlitteratur ur den svenska och västerländska litteraturen där det efterlämnade tomrummet har kunnat fyllas med något nytt. De flesta kan karaktäriseras som bilderböcker, men också exempel från barnromanen och den tecknade serien finns med. Jag börjar med en genomgång av burkens funktion och fortsätter med kartongens.

\section{Burken - mer än skräp}

I Astrid Lindgrens första bok om Pippi Långstrump (1945) ger sig huvudpersonen ut på sakletning tillsammans med Tommy och Annika. Det är en välkänd scen, liksom Pippis fynd, en tom trådrulle och en rostig plåtburk. Tommy är tveksam till Pippis glädje över burken och undrar vad man kan ha den till, varpå Pippi beskriver den som en kommande"trevlig Burk Med Kakor i", eller som en "Burk utan Kakor", visserligen inte lika trevlig men bra ändå eftersom den kan duga till att leka mitt i natten med. Pippi sät- 
ter den på huvudet och vandrar vidare som ett litet plåttorn genom villakvarteret tills hon står på huvudet över ett stängsel. "-Där ser ni, sa Pippi och tog av burken. Hade jag nu inte haft den här på mig, så hade jag trattat direkt på ansiktet och slagit mig fördärvad." Annikas invändning, att hon aldrig hade snavat över staketet utan burken, lyssnar hon förstås inte på.

För Pippi är varje ting fyllt av möjligheter till lek och upptåg. En rostig burk är långt ifrån skräp för henne, medan Tommy och Annika bara ser den som avfall utan någon som helst funktion. Lindgren laddar först burken med en dröm om kakor och gör den sedan till förutsättningen för en lekfull promenad i omgivningen.

I Tove Janssons bilderbok Hur gick det sen? (1952) är Mumintrollet på väg hem till sin mamma med en kanna mjölk genom bokens utskurna sidor.

"Men det var inte mammans hus / blott mymlan som i randig blus / satt på en gammal burk av plåt / och grät så klänningen blev våt / och sa: min lillasyster My / har för en stund sen lyckats fly! / Men Mumintrollet sade: Nej, / Min kära Mymla, lugna dej, / hon är nog gömd av någons skurk, / kanhända just i denna burk! / Kom ska vi krypa in i den! / Vad tror du att det hände sen?"

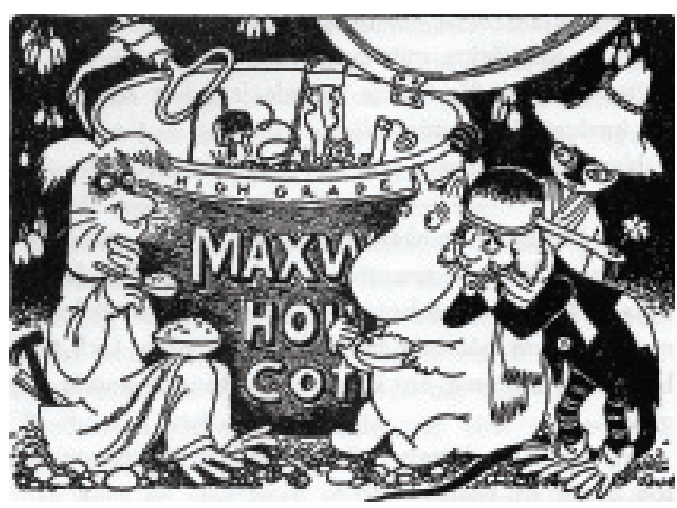

III. Tove Jansson ur Muminpappans memoarer.
Den behållare som är intressantast i Janssons bok är utan tvekan mjölkkannan, substitutet för mamman, modersmjölken, eller som symbol för henne som husmor och utdelare av uppdrag till mumintrollet, utföraren. ${ }^{2}$ Men konservburken är också intressant, med sin rent bokstavligt bortskurna botten som öppnar upp mot nästa uppslag och vidare äventyr. Pippis burk är en ingång till stollerier och tokigheter, Mumins är en port i historien in i nya världar och mot det efterlängtade målet, modern.

\section{Burken som byggmaterial}

Konservburken är återanvänd i dubbel bemärkelse, den skymtas redan i serien "Mumintrollet och jordens undergång" från tidningen Ny tid 1947 och 1948. Där träffar Rådd-djuret och Mumintrollet snusmumriken som slagit läger i en burk med texten Lyles Golden Syrup, vilket antyder trollens storlek i förhållande till burkens tillverkare. Senare för även denna burk personerna vidare i äventyret, som hytt på de tre resenärernas flotte. ${ }^{3}$ En kaffeburk används också i Muminpappans memoarer (1968), först som bostad och sedan som båt till Rådd-djuret. Bilden av burken säger mer än texten, den ger liksom den tecknade serien en vink om mumintrollens storlek. Och att märket är Maxwells. Det ger också läsaren något reellt från dess egen värld, såsom Christina Björk skriver: "Jag fäste mig särskilt vid Rådd-djuret som bodde i en amerikansk kaffeburk av den blåa sorten (Maxwell-house, vi hade den hemma också)." ${ }^{4}$ Konservburken som bild av bostäder, även använt omvänt i beskrivningen av de moderna villorna, byggda som "en hyllning till det tekniska framåtskridandet på så sätt att de ropar på att bli bortslängda som konservburkar efter kortvarig användning. ${ }^{5}$ Och visst kan man konstatera att Mumindalen är fylld av tillfälliga bostäder, påminnande om det flyktiga och 
tillfälliga, som Theodor Adorno och Max Horkheimer kritiserar med sin konservburksmetafor. Det som är bildligt i citatet blir bokstavligt hos Jansson.

"Vad ska du göra med allt det där skräpet?" frågar mamman i boken Vad lilla Anna sparade på (1965) av Inger och Lasse Sandberg, och intar således Tommys roll som ifrågasättare. I efterföljelse av Elsa Beskows Hattstugan (1930) utelämnar författarna i texten namnen på de sparade sakerna till barnens gissning, men där Beskow tar rimmet till ledtråd skapar Sandbergs rebusar med bilder av de hittade tingen, bl.a. en låda och några burkar. Anna visar sin mor att det hon samlat är mer än skräp genom att skapa en bil, en båt, ett hus och ett flygplan där burkarna ingår som billampor, mast, skorsten och flygplansroder. Hon agerar alltså inte på Pippis anarkistiska sätt, där burken blir till en ihopsamlande behållare för hennes fantasi, utan hon bygger utifrån dess utseende, som hos Tove Jansson. Men Pippi och lilla Anna förenas ändå i att de båda är praktiska, självständiga och skapande barn. I Muminpappans memoarer är det författaren som är skapare av burkarna och vi får aldrig se eller ana någon process där djuren själva förvandlar burkarna. Det är också osäkert om djuren är medvetna om vad burkarna egentligen används till ursprungligen.

\section{Förpackningen som livmoder...}

Hos Sven Nordqvist får katten Findus sitt namn från konservburkarna med gröna ärtors varumärke då han kommer med grannfrun i en låda som förut innehållit just dessa. När Findus var liten och försvann (2001) är en analeps till de tidigare böckerna, en återblick och samtidigt en avslutning av serien. ${ }^{6}$

Vad är detta? sa gubben och läste på lådan. 'Findus. Gröna ärtor' står det. Det piper. Han öppnade lådan och där, på en grönrandig

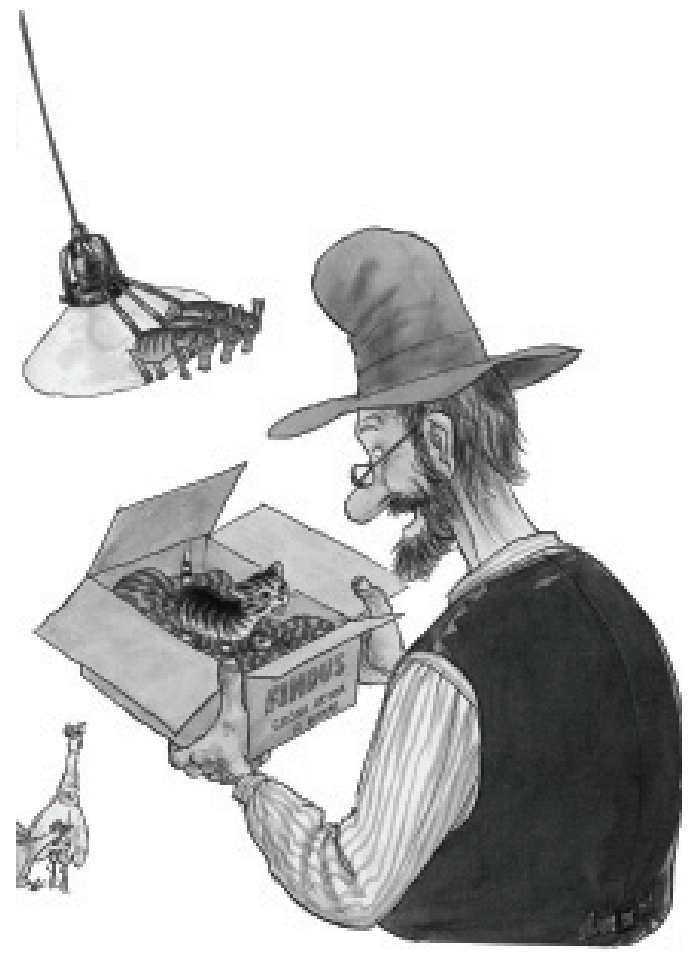

III. Sven Nordqvist ur När Findus var liten och försvann.

tygbit, stod en kattunge. Den såg Pettson rakt i ögonen och pep. 'hej Findus gröna ärtor', sa Pettson och det kändes i honom som när man drar upp rullgardinen en sommarmorgon och det varma solljuset strömmar in

Kartongen gör det omöjligt att fortsätta serien med böcker utan tidens närvaro och några nya berättelser om Pettson och Findus har inte utgivits. Kartongen blir berättelsens moder, livmodern och starten på berättelsen, men den blir också genom sin upplysning om kattens tillkomst en föderska av tanken på dess död, medan burkarna ger barnet, katten, sitt namn. Nordqvist låter Pettson associera fritt; Findus gröna ärtor må ha varit konservburkar med detta innehåll, men det blir namnet på hans skyddsling och upptågsmakare.

I Christine Nöstlingers Burkpojken (övers. Karin Nyman 1975) kommer barnet rent 
konkret direkt ur burken. Författaren använder en jättelik konservburk som livmoder åt pojken som fraktas från fabriken där han tillverkats, hem till fru Berti Bartolotti som häpet öppnar den. Nöstlinger skojar med det samhälle där det mesta kan konserveras och fraktas över hela jordklotet, där nästintill vad som helst kan stoppas i burkar. Det blir också ett inslag i debatten om utomkroppslig befruktning, provrörsbarnet blir till konservburksbarnet.

\section{...och burken som civilisationskritik}

Fru Bartolotti befarar i Burkpojken att det är en enorm burk med corned beef som hon av misstag beställt, innan hon har öppnat den. I Hergés Tintin i Amerika (1945) är hjälten och hans hund nära att bli nermalda till just detta. "Om bara Slift \& Co visste vad det är för ingredienser som används i tillverkningen av deras konserver" säger en av berättelsens skurkar då han tror att de två blivit ordentligt finfördelade. Även i Hergés berättelse är konservburken en del av det stora kapitalistiska systemet där allt kan göras till varor. Konservburken används som ett redskap för lurendrejeri och mygel. I den kan man stuva ner vad som helst och kalla det för vad som helst. Skurken har innan sitt dåd förklarat fabrikens idé.
Bilfabrikerna skickar oss gammalt bilskrot som vi gör till konservburkar för corned beef, med kvalitetsgaranti. Från vårt håll ser vi till att våra ombud över hela världen samlar ihop gamla konservburkar som vi skickar till bilfabrikanterna, som tillverkar en supersportbil med stor framgång [...]. Ser ni den här enorma maskinen? Nåväl! Nötkreatur åker in här på rullbandet ett efter ett och de kommer ut på andra sidan som corned beef, korvar, frityrolja... Allt sker helautomatiskt.

Konservburken som behållare för brottslighet är än tydligare i Krabban med guldklorna (1943). Albumet inleds med att Milou kör ner nosen i en konservburk med en gyllene krabba på den söndriga etiketten. Tintins upptäckt av den saknade pappersbiten leder honom in i det smugglingsäventyr där han instängd i ett lastrum finner att burkarna innehåller opium. ${ }^{7}$ Även hos den författare vars matscener alltid kommenteras, Enid Blyton, "förekommer en och annan konservburk och annan fabriksmat, men det är mat av helt annat slag som får en speciell lyskraft: den pastorala och agrara, hemproducerad och hemlagad." ${ }^{8}$ Konservburkarna pekas här ut som kontrastskapare, de visar på hur god mat skall vara. Konserven hör inte riktigt hemma i den pastorala idyllen. Den kan

Bilden visas endast
i den tryckta
utgåvan av
Barnboken


alltså vara enbart skräp, och även kritisera vårt förhållande till miljön, som i Vägen till Saga (2000) av Kajsa Grytt och Maja Lindén där colaburken ses i mänsklighetens avfallssoppa kokad av kloakernas häxa. I Nällson och King Edvard i blåsväder (1994) av Barbro Ekström och Anders Suneson används burkarna till att samla in olika slags väderlekar som sammanblandas i olika experiment, vilket håller på att leda till jordens undergång då inget 'väder' finns kvar.

Hos Lindgren, Jansson, Sandberg och Nordqvist är burken en cylinder, eller i Nordqvists fall ett namn, som kan fyllas med ett nytt innehåll, en lek eller ett äventyr. Den har likheter med folksagornas magiska ting som leder hjälten till nya världar och in i äventyren. De är ämbar för fantasin liksom den magiska flaskan är det för anden.

Hos Nöstlinger och Hergé är burken en del av den moderna världen, det "helautomatiska" samhälle där konserverna synes vara den mest utmärkta förpackningen. Kritik framförs på ett subtilare och inte lika en- tydigt sätt som i Vägen till saga och berättelsen om King Edvard. Här finns bortom det komiska och underhållande en mörkare underton, hos Hergé ett ifrågasättande av den anonyma och okontrollerbara föda som burken tillhandahåller, och hos Nöstlinger en sorglig ensamhet runt den kvinna som inte tillsammans med en man skapar sitt barn utan plockar fram honom ur en burk. Det är fantasifullt men tragiskt.

\section{Burken och ensamheten}

Nöstlingers text bär på en ensamhet som också finns i Eva Lindströms Min vän Lage (2001) där den urbaniserade ugglan nyss inflyttad från landet äter sin mat ur konservburkar. Motivet har ett avlägset släktskap i T.S. Eliots Det öde landet (1922) där kvinnan kommer hem efter en hård arbetsdag till sin slitna lägenhet och äter direkt ur den nyöppnade burken. ${ }^{9}$ Men också Barbro Lindgrens "Två burkar" ur Vi leker att du är en humla (2000) bär på tragik i de två barnen, personifierade av läskburkar, som letar efter sina

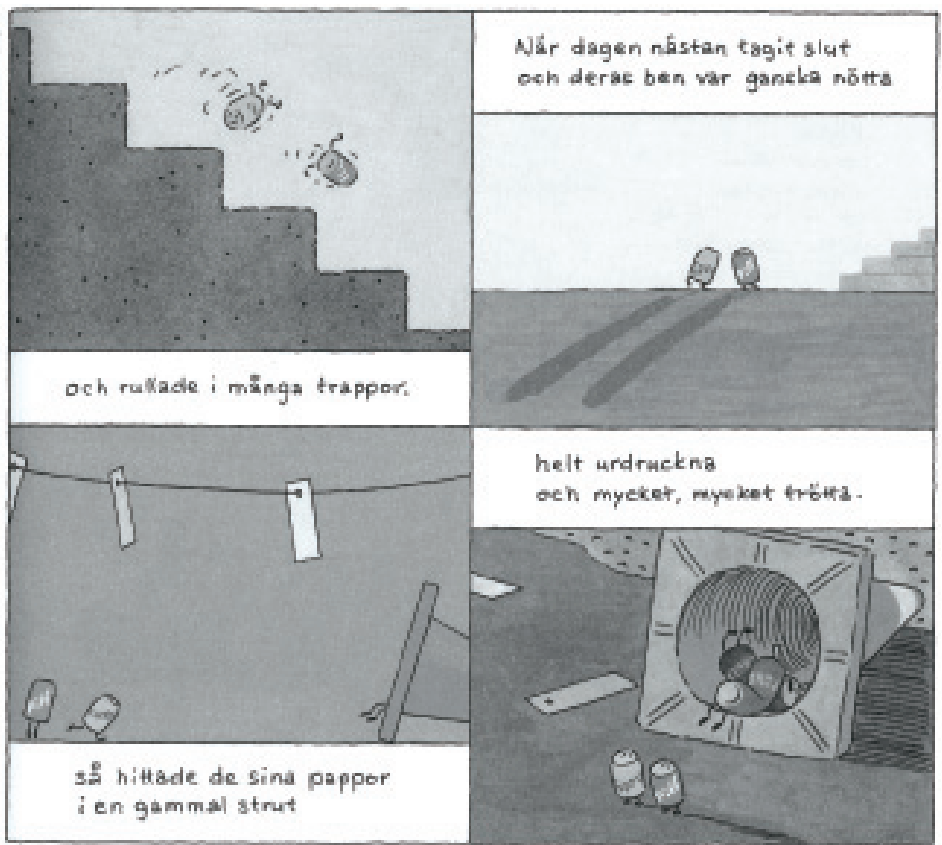

Olof Landström ur Vi leker att du är en humla. 
pappor, ölburkarna, lika alkoholiserade, trötta och utslagna som de fäder som nyttjar drycken i allt för hög grad. Valet av förpackning till fäderna är genomtänkt. Papporna blir till det som reducerar dem som föräldrar och utlämnar barnen till övergivenhet och ensamhet. Förpackningen till kroppen väljs efter produktens egenskaper, på samma vis som P. Sävström väljer en senapstub med klämmande och korvgörande talanger till sin bok Bajsmannen (2001).

Som symbol för oförstående och oförmåga att lyssna till en annan människas berättelse, och därigenom en ensamhet både för den som talar och den som inte lyssnar, står kaffeburkarna i Anna Höglunds Mina i Kina (1999). Mina kommer hem till Kåge från det stora landet i öster och försöker berätta om de fantastiska upplevelser hon varit med $\mathrm{om}$. Men han är fast i sin egen vardag vilket skapar både komiska och tragiska kontraster gentemot Minas berättelse. "Det var extrapris på kaffe i mataffären. Två burkar till det facila priset av en" säger Kåge och viftar med burkarna i Höglunds bild. Mina försöker förgäves berätta om templet och den underliga maten.

\section{Den förste och störste burkförvandlaren}

Den som först och med störst genomslagskraft lät konservburken bli något annat än cylindern för mat är konstnären Andy Warhol. Hans bilder av Campbells soppburkar har blivit en ikon för ett nytt sätt att se på konst - och på de vardagsföremål vi har omkring oss. Hans brorson James Warhola berättar i sin bok Farbror Andy (övers. Peter Törnqvist 2004) om ett besök hos sin excentriske farbror. Och i den boken finns många av de ovan beskrivna sätten att se på burken med, liksom andra överblivna ting från vårt konsumtionssamhälle. Möjligheternas syn-

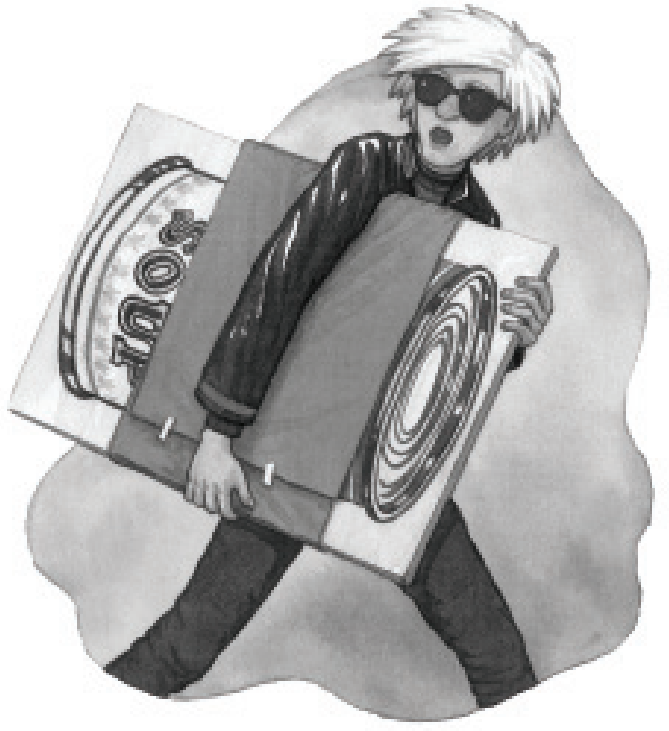

III. James Warhola ur Farbror Andy.

sätt vinner över den som beskriver burkar och kartonger som avfall.

James pappa är skrothandlare. Han älskar sitt arbete och i varje ting ser han olika möjligheter; till inkomst, till lek för barnen, eller som gåva till brodern Andy. Mamman representerar inledningsvis samma uppfattning som Tommy i Lindgrens bok. "För guds skull, Paul, måste du skräpa ner hela huset!", medan pappan säger: "Titta på det här, Jamie, det kan nog bli nåt." Och så sammanför han olika skrotdelar till nya spännande leksaker. På pappa Pauls gårdsplan finns många ting likartade de som hos farbror Andy förvandlas till konst.

Deras resa till farbrodern går genom de sju tunnlarna och sedan öppnar sig staden över ett helt uppslag, reklamskyltarna och neonen anfaller. James Warhola visar med tydlighet upp den värld där konservburken blir till konst och han låter sitt eget alter ego vakna upp mitt bland alla de av konstnären skapade kartongerna för Campbells soup. Det är ett bokstavligt uppvaknande till vad konst kan vara och vad skapande kan bestå 
av. Målningarna av Campbells burkar finns överallt i boken, liksom burkarna själva.

Boken avslutas med att Jamie sitter på sitt rum och tecknar av ett föremål hämtat från skrotgården. Hans mamma tvingar honom inte längre att städa. Och hon kör honom tidigt om lördagsmorgnarna till konstskolan. "Jag tror faktiskt att mamma till slut förstod vad konst egentligen handlar om." Burken blir även i hennes värld någonting annat än skräp.

Men den fantasi vi upplever hos konstnärerna och författarna som omskapar burken och fyller den med ny betydelse, är egentligen inte originellare än den lek barnet själv skapar med det som finns till hands, i vår del av världen $i$ all enkelhet, som torn och staplar, eller som byggmaterial till avancerade fordon i områden där fabrikens leksaker lyser med sin frånvaro.

Skräp är mer än skräp. De till synes triviala föremålen i folksagan som leder till äventyr, förvandlingar och förtrollningar har fått sin förlängning i den industrialiserade tillvarons förpackning. Rund och rullbar åt många olika håll, tom och tänkbar för alla typer av innehåll; vidare världar, öppnare ögon, nya idéer och individer, eller, för kritik av det konsumtionssamhälle som skapat den, burken.

\section{Kartongen som medel för frigörelse och protest}

Lådan och pappersförpackningen kan också bli till bostäder. Med sin kantiga form förvandlas de till hus och byggnader, exempelvis i Michael Bonds Nalleberättelser (1993) där Teddy Robinsson får ett eget hem av en låda med specerier som han så duktigt kunnat ta emot på familjens trappa. Han har suttit på lådan och drömt om ett eget hus, med en egen kökstrappa, och drömmen går i uppfyllelse. Man kan se det som det lekande bar- nets dröm, som barnets frigörande lek i att skapa sig ett eget hem.

Inflyttningen kan också vara en protest mot vuxenvärlden och dess utestängande, som i Inger och Lasse Sandbergs Hjälpa till, sa Pulvret (1983). Morfar låter inte Pulvret vara med i köket och Pulvret flyttar då in sina leksaksfigurer i de paket och förpackningar som behövs i matlagningen. Bosättningen, eller ockupationen, blir ett sätt att skapa sig ett eget revir och territorium förknippat med matlagningen som han inte får deltaga $i$, som en protest just mot att han inte tillåts ta ansvar och vara en deltagande individ. ${ }^{10}$

Förpackningarna kan också bli till hus och städer, som i Pluttens pappa (1989) av Bjørn Rønningen. Fadern beskrivs med sina misslyckanden men älskas av sin son och lyckas som arkitekt till den fästning av mjölkkartonger som de skapar. Pappan uppvärderas i leken på samma vis som Michael Bonds nalle blir en fullvärdig medborgare i sin av förpackningen tillverkade bostad. Illustratören Vivian Zahl Olsens pappa håller i två paket som har tetrans toppiga tak och bredvid honom och Plutten står det färdiga bygget, målat och förvandlat. I det slutna hemmets kokong kan yttervärlden genom paketen struktureras och underläggas den chef som aldrig annars får vara överste.

\section{Den fantastiska kartongvärlden}

Den som av förpackningar åstadkommer den mest storslagna staden är Maurice Sendak i boken Nattköket (1970). Vardagens föremål blandas där med en teatral fantasi, ${ }_{11}^{11}$ paketen bildar fonden för historien, förpackningar och föremål från hans barndoms kök i Brooklyn skapar en karikatyr av New Yorks skyline i den fristående fortsättningen på hans mest kända bok Till vildingarnas land (1963). Där försvinner Max i sin vargdräkt till vildingarna om kvällen när han 
blivit skickad i säng och i Nattköket är det Mickey som ligger nedbäddad men inte kan somna eftersom det slamrar och bullrar i undervåningen. Han stiger ur sin säng och faller likt Alice i Underlandet genom golvet, ur sina kläder, förbi mamman och pappan och ner i den smet som de tre bagarna rör ihop.

Redan bokens framsida avslöjar paketens funktion. Mickey reser mot månen i ett flygplan av deg och runtomkring honom finns stadens hus, en civilisation innesluten i köket. Mickey blir som Pluttens pappa en världshärskare på hemmaplan. Han visar att han är stor och det finns i bakgrunden till boken också likheter med Pluttens tilltag. Sendak berättar om en slogan till ett av New Yorks bagerier, "We Bake While You Sleep!", det mest sadistiska han kunde tänka sig. Hur kunde reklamens tre små tjocka bagare få ha roligt medan han måste sova? Han beskriver Nattköket som en vendetta då han blivit stor nog för att få stanna uppe på natten och ta redan på vad som händer i nattköket. ${ }^{12}$ Hela boken kan alltså ses som en protest mot vuxenvärldens utestängande, precis som Pluttens ockupation av paketen. Mickey är tillräckligt stor för att få vara med, han vinner över kockarna och förpackningarna. Enligt en annan beskrivning räddar han också likt en hjälte brödbaket från den fullständigt anonymiserade fabriksframställningen, symboliserad av paketen som vuxit upp till en stad..$^{13}$ Med den tolkningen får förpackningarna likheter med Hergés, som symboler för matframställningen avskild från människan. Men hos Sendak behövs pojken för att komma åt mjölken, drycken förknippad med modern och det mänskliga i kontrast mot det industrialiserade.

Storstaden bestående av paket, flaskor och burkar har alla sina etiketter kvar, som jättelika väggreklammålningar, men de har också fått dörrar och fönster, som det lyser ur i natten. John Cech, som analyserat Sendak, skriver att han gått tillbaka till sina rötter, 1930-talets kök.

Sendak built this fantasy world out of familiar things, the sort of detritus of everyday life that fascinates us as young children: the egg beaters, whisks, funnels, and other utensils that, if turned upside down, could well become a tower of a building; the packages of baking soda and jars of jam and pickles that, if lined up on a shelf or counter and viewed from the diminutive perspective of a four-year old an a dimly lit kitchen, could well resemble the skyline of a city. ${ }^{14}$

De hör samman med den massmarknadskultur som enligt Cech utövade och utövar en ständig påverkan på miljoner barn från tidig ålder, inklusive Sendak. Uppvägandet av detta med mera sofistikerade influenser kastar han över bord i Nattköket. Han visar istället sina rötter och sitt beroende:

\footnotetext{
"this stuff now, this the only art I grew up with. And for some reason I find it very important. The cheap crap I had to grow up with is what made me. Those movies and Mickey Mouse. And I love it!"15
}

Boken har den tecknade seriens karaktär och han upphöjer uttrycket till konst, liksom Andy Warhol skapat konst av det han har omkring sig, burkarna och förpackningarna. Dem infogar Sendak på ett Warholskt vis i sin bok, barndomens förpackningar, som också hör till de intryck av illustrationer och bilder han vuxit upp med. De sammanfattar också hans liv; Selma G. Lanes redogör för vilka vänners namn som blivit varumärken, vilka siffror som pekar ut födelseår och adresser från barndomen. ${ }^{16}$ Förpackningarna ger biografiska ledtrådar, de informerar den invigde om berättelsens anknytning till författarens liv.

Den förpackning som skiljer sig från de 


\begin{tabular}{|l|}
\hline Bilden visas endast \\
i den tryckta \\
utgåvan av \\
Barnboken
\end{tabular}

III. Maurice Sendak ur Nattköket.

övriga och som Mickey flyger upp till i sitt plan från degen är mjölkflaskan. Mjölkbudets glasflaska, stadens högsta punkt, utmärkandes i sin avsaknad av etikett, likt ett tempel fri från reklam och fylld med den åtråvärda drycken. Cech förklarar mjölkflaskan som en kraftfull souvenir för dem som minns tiden med dem, och för barnen som bara känner till de vaxade papperspaketen står den som en skulptur från ett arkaiskt förflutet "that cannot be claimed by the omnipresent semiotics of product labels." ${ }^{17}$

Mickey sjunker ner i flaskan och ur sin dräkt av deg medan han sjunger: "Jag är i mjölken - mjölken är i mig. Gud välsigne mjölken och Gud välsigne mig!" Mjölken sägs komma från vintergatan, stjärnhimlen som omger köksstaden. Utanför den, ovan- 
för stjärnorna finns föräldrarna, finns mamman. Hon intar Guds plats. Pojken återförenas med henne, han hämtar mjölken, han klarar sitt uppdrag, han föds på nytt. Han ropar: "Kuckeliku!" och faller från mjölkflaskan tillbaka i sin säng. Det handlar om den eviga triangeln, Modern - sonen - mjölken, som vi också sett exempel på i berättelsen om Mumintrollet och mjölkkannan.

\section{Den skrämmande skräpverkligheten}

Joseph Stanton menar att Sendak inte har några problem att välja mellan fesagan och den urbana miljön. "The strategy of several of his best books has been to intermix the fairytale fantastic with the urban moment mundane to create new and unusual works".$^{18}$ Cech beskriver detta, hur Sendak tagit intryck från folksagan och myterna, hur Orfeus nedgång i dödsriket kan ses i Mickeys neddykande i mjölkflaskan. ${ }^{19}$ Sendak har pekat ut Mozarts musik som en av sina inspirationskällor, exempelvis Trollflöjten som han också skapat scenografi till. ${ }^{20}$ Och det är något av trollflöjtens magiska teaterkraft som lagt sig över paketen och scenbilden till nattköket. Lanes beskriver den som "musical extravaganca" ${ }^{21}$ och samma typ av paketstad finns med i manuskriptet till hans tecknade musikalfilm från 1975, Maurice Sendak's Really Rosie starring the Nutshell Kids (u.å.) där burkar med chicken soup sträcker sig mot natthimlen som en bakgrund till ett dansnummer. I boken We Are All in the Dumps with Jack and Guy (1993), saknas kycklingsoppan, Manhattan har blivit en mardröm. ${ }^{22}$ Peter Neumeyer pekar ut den kontext boken kan ses mot, Jacob Riis foton av gatubarn, aidsepidemin, Afrikas svält osv. ${ }^{23}$ Men här finns också paketen, de är kvar men har ändrat karaktär. Inga leksaker flyttar in, ingen drömstad att bemästra skapas. Kartongerna och pappersskräpet är det enda som ger något skydd, det som är gatubarnens riktiga bostad. Det är en bild hämtad ur vår verkliga värld, paketen påminner om den och de är alltså inte bara en grund för lek, liknande solstickeaskens funktion i Jan Lööfs Pelle möter en riddare (2004), där det moderna paketet bryter av mot den medeltida fantasin och påminner om världen utanför. Men Jack och Guys paket bär på en allvarligare botten, i större släktskap med Hergés burkar. De är bärare av kritik mot hur samhället utvecklats.

Sendaks texter innehåller alltså de flesta av förpackningarnas funktioner i barnboken; som hos Pippi och Mumintrollet är de en öppnare till den magiska världen, och en förenare av fesagan och det urbana landskapet.

Som hos Teddy Robinson deltar de i en frigörande process eller som för Pulvret i en protest mot vuxenvärlden och dess utestängande. Som hos lilla Anna visar de på barnets kunnande, och som hos Pluttens pappa skapar de en kompenserande värld för den verkliga, en egen verklighet som man kan bemästra.

Max kommande ur mjölkflaskan är en symbol för födelsen likt burkarna och kartongen för Findus och burkpojken.

De finns som en ledtråd till författarens i boken nedlagda biografi, likt Janssons Maxvells-burk, och som en anknytningspunkt till läsarens värld och miljö. Sendak gör också som James Warhola, förhöjer vardagens föremål, förpackningarna, till konst.

Som hos Hergé m. fl. finns förpackningarna som en kritik av vårt sätt att leva, en symbol för den helautomatiserade matframställningen och i den sista Sendaktexten, en skildring av den värld där tomma paket inte bara blir behållare för lek och fantasi utan även ett hem för de små som inte har någonstans att bo. 


\section{Noter}

${ }^{1}$ Helena Mattsson, Arkitektur och konsumtion. Reyner Banham och utbytbarhetens estetik diss. (Symposion, 2004) s. 44

${ }^{2}$ Lena Kåreland, Barbro Werkmäster, Livsvandring $i$ tre akter. En analys av Tove Janssons bilderböcker Hur gick det sen? Vem ska trösta knyttet? Den farliga resan (Svenska barnboksinstitutets skrifter nr 54, 1994) s. 21 ff. De hänvisar sitt resonemang om utdelare av uppdrag och utförare till Propps strukturanalys för sagans funktioner. Det gör även Boel Westin i sin avhandling Familjen $i$ dalen. Tove Janssons muminvärld (Bonniers, 1988) där hon beskriver Janssons bok Kometjakten i en formel som i stort liknar upplägget i Hur gick det sen?

${ }^{3}$ Juhani Tolvanen, Vid min svans! Tove och Lars Janssons tecknade muminserie (Schildts, 2000) s. 33. Jordens undergång är också bakgrunden till Janssons novell "Shopping" i Resa med lätt bagage (1987) där föda endast finns i överblivna konservburkar.

${ }^{4}$ Christina Björk: Tove Jansson - mycket mer än Mumin (Bilda, 2003) s. 14.

${ }^{5}$ Theodor Adorno, Max Horkheimer, Upplysningens dialektik: filosofiska fragment övers. Lars Bjurman och Carl-Henning Wijkmark (på tyska 1969, Röda bokförlaget, 1981) s. 137.

${ }^{6}$ Analepsen beskriver Maria Nikolajeva i Bilderbokens pusselbitar (Studentlitteratur 2000) som en "sekundärhistoria som tidsmässigt ligger före det primära." s. 222. Boken inleds med att Findus ber Pettson att berätta om när han var liten, och den berättelsen upptar huvuddelen av boken. Men berättelsen blir inte bara en analeps i det enskilda verket utan också en analeps för hela bokserien.

${ }^{7}$ I essän "Tintin, tekniken och politiken" av Michael Godhe och Elin Frykman i Tvärsnitt nr 4, 2000, beskrivs bl.a. Tintinalbumens bild av tekniken och dess roll hemmahörande hos skurkarna eller hjältarna - dock utan några förpackningar med i perspektivet.

${ }^{8}$ Eva Löfgren, "Möss och människor: Maten i det pastorala England" i Läckergommarnas kungarike - om matens roll i barnlitteraturen red. Ulla Bergstrand och Maria Nikolajeva (Centrum för barnkulturforskning vid Stockholms universitet 1999) s. 85.
${ }^{9}$ Burkens roll i lyriken kommer att utvecklas mera i ett kommande nummer av tidskriften Horisont under 2005.

${ }^{10}$ I Tove Janssons vuxenlitteratur, Sommarboken (1972) finns också ett exempel på förpackningen som en bild av barnets frigörelse. Så "tog hon fram den heliga asken Lupatro för nu var den tom och Sophia kröp in i grottan igen och lade den på altaret." s. 61. Birgit Antonsson skriver i Det slutna och det öppna rummet. Om Tove Janssons senare författarskap (Carlssons 1999): "På lekens plan skall den [medicinasken] stå inne på grottans altare - för Gud att bo i. Men även asken [och inte bara grottan] kan uppfattas som en bild av Sophias [barnet] kommande liv som kvinna." s. 76.

${ }^{11}$ Joseph Stanton, "Maurice Sendaks's Urban Landscape" I Children's literature (Storrs, Conn. vol. 28, 2000 s. 132-146) s. 132.

12 "Questions to an Artist Who Is Also an Author: A Conversation between Maurice Sendak and Virginia Haviland" i Quarterly Journal of the Library of Congress 28, no 4 1971, s. 276

${ }^{13}$ Kara Keeling och Scott Pollard, "Power, Food and Eating in Maurice Sendak and Henrik Drescher: Where the Wild Things Are, In the Night Kitchen, and The Boy Who Ate Around" i Childrens Literature in Education (Vol. 30, nr 2 1999) s. 136.

${ }^{14}$ John Cech, Angel and Wild Things. The Archetypal Poetics of Maurice Sendak (The Pennsylvania State University press 1995) s. 196.

${ }^{15}$ Ibid. s. 188 f.

${ }^{16}$ Selma G. Lanes, The Art of Maurice Sendak (Abradale Press/ Harry N. Abrams, Inc. 1980, 1993) s. $182 \mathrm{f}$.

${ }^{17}$ Cech, s. 206

18 Stanton s. 134

${ }^{19}$ Cech s. 208.

${ }^{20}$ Lanes s. 266

${ }^{21}$ Ibid. s. 182.

${ }^{22}$ Stanton s. 143.

${ }^{23}$ Peter Neumeyer, "We are all in the dumps with Jack and Guy: Two Nursery Rhymes with Pictures by Maurice Sendak" i Childrens Literature in Education 25 (nr. 1 1994) s. 29-34. 